Rok XV (2020) | 1 (29) | S. 201-212

https://doi.org/10.12797/LV.15.2020.29.13

Paweł Janczulewicz ๑

Instytut Języka Polskiego Polskiej Akademii Nauk, Kraków

pawel.janczulewicz@ijp.pan.pl

\title{
IDENTYFIKACJA TEMATÓW NA *-(J)Ū W MATERIALE POLSKIM I SŁOWIAŃSKIM
}

Słowa klucze: język prasłowiański, collectiva, substytucja sufiksów

Keywords: Proto-Slavic language, collective nouns, suffix substitution

Przeglądając rozdziały poświęcone tematom na ${ }^{*}-(j) \bar{u}$ w różnych gramatykach porównawczych języków słowiańskich, trudno nie oprzeć się wrażeniu, że głównym kryterium determinującym uznanie wyrazu za pierwotny temat na ${ }_{-}-(j) \bar{u}$ jest obecność segmentu - $v$ - w przekazie historycznym tuż po części rdzennej. W większości przypadków jest to kryterium wystarczające, jednak - według moich podejrzeń trafiają się wyrazy, w których - $v$ - (a nawet historyczna kontynuacja fleksji na ${ }^{*}-\bar{u}$ ) może być innego pochodzenia, jak i takie, które na poziomie segmentalnym nie pokazują żadnego związku z tematami na ${ }_{-}-(j) \bar{u}$, a jednak się z nich wywodzą.

W niniejszym artykule staram się poruszyć kilka zagadnień rzadko (albo wcale) opisywanych w pracach dotyczących tematów na ${ }^{*}-(j) \bar{u}^{1}$. Rozważania składają się z dwóch części. Celem pierwszej jest wskazanie w materiale polskim i słowiańskim femininów atematycznych, w których sufiks *-øka pełniłby funkcję strukturalną, jednak nie byłby dodawany bezpośrednio do tematu, ale substytuował sufiks tematyczny ${ }^{*}-\approx v-$. W drugiej części tekstu skupiam się na skategoryzowaniu wyrazów uważanych za tematy na ${ }^{*}-(j) \bar{u}$ pod kątem pochodzenia ich fleksji (lub tylko segmentu ${ }^{*}-v$-), jak i ogólnych kryteriów pozwalających identyfikować bądź postulować temat na ${ }^{*}(j) \bar{u}$.

1 Tematy te szeroko omówili np. André Vaillant (1958: 262-290), Samuel Bernstein (1985: 266-291) i Peeter Arumaa (1985: 63-68, 93). 


\section{Sufiks *-ъka jako składnik substytuujący sufiks tematyczny}

Funkcja strukturalna sufiksu ${ }^{\star}-k z$ jako elementu przenoszącego rzeczowniki z klasy atematycznej do tematycznej została rozpoznana już dawno, por. ${ }^{\star} k a m y-k r \leftarrow$

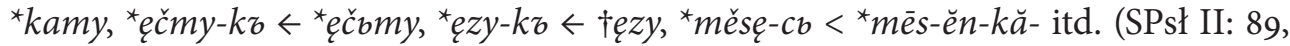
97). To samo zjawisko zostało zaobserwowane również w neutrach typu ${ }^{\star} b e r m e ̨-c-$ -bko : *bermę-č-bce, sěmę-č- $b k o:$ sěmę-č-bce (Boryś 1974: 123).

$\mathrm{W}$ materiale słowiańskim możemy odnaleźć kilka par rzeczowników, które albo są włączone do typów kontynuujących deklinację na ${ }^{*}-(j) \bar{u}$, albo wykazują strukturę rdzeń + sufiks ${ }^{*}-\imath k a$, jednak potencjalnej podstawy derywacyjnej dla tych ostat-

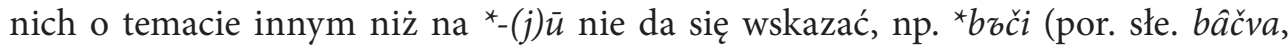
serb. bäčva, strus. бъчbbb, stcz. bečvár̆ 'bednarz') : ${ }^{\star} b r c ̌ c k k a$ (pol. beczka, cz. bečka, ros. бочка); ${ }^{\star}$ nъti (ros. dial. ночва, ch. näćve, cs. нбщви) : ${ }^{\star}$ nьtıka (pol. niecka, stcz. necky); ${ }^{\star}$ laty (strus. патовъ, słe. látva) : ${ }^{\star}$ latzka 'rodzaj garnka' (stpol. łatka, stcz. látka); ${ }^{\star} k o t y$ (stpol. kotew) : ${ }^{\star} k o t z k a$ (stpol. kotka 'kotwica'). Formy te bywają interpretowane bardzo różnie, co dobrze widać na przykładzie apelatywu ${ }^{\star} b z c ̌ z k a$. Niektórzy w sufiksie *-øka widzieli formant przyswajający wyrazy obce (SPsł I: 94, 458-459), inni - wbrew wokalizmowi i rodzajowi - szukali podstawy derywacyjnej w słe. bùč m., boč m., beč m., serb./ch. bùča (ESSJ III: 108), wreszcie część badaczy traktowała to jako deminutivum do ${ }^{\star} b r c ̌ c i$ (SEBań I: 39; SEBor: 24). Hipoteza o deminutiwach jest trudna do podważenia, jednak do zaprezentowanej wyżej grupy można dodać kilka par, w których podstawa derywacyjna nie zawsze została właściwie wskazana, i zastanowić się, czy sufiks * ${ }^{\star}$ øka nie pełni w nich funkcji strukturalnej. Identyfikacja takich przypadków opiera się na następujących założeniach:

1) istnienie przesłanek chronologicznych do uznania form $z$ sufiksem ${ }^{*}$ - $k k a$ za starsze od form niesufigowanych;

2) realne zaświadczenie formy wyrazu kontynuującej typ odmiany na ${ }^{*}(j) \bar{u}$;

3) brak znaczenia deminutywnego derywatu.

1.1. Formy ${ }^{\star} k r u s ̌ b k a /{ }^{*}$ grušbka kontynuowane przede wszystkim w językach zachodniosłowiańskich i zachodniej części południowej Słowiańszczyzny (słoweński, kontinuum dialektalne serbsko-chorwackie) najczęściej uważane są za pochodne od ${ }^{*} k r u s ̌ a /{ }^{*} g r u s ̌ a$, co na pozór jest interpretacją słuszną. Obraz jednak staje się mniej jednoznaczny, gdy uwzględni się dane historyczne i dialektalne. Według Ogólnosłowiańskiego atlasu językowego nazwa gruszy (drzewa) i gruszki (owocu) dzieli Słowiańszczyznę na dwa areały: formy wschodniosłowiańskie, bułgarskie i macedońskie na oznaczenie drzewa sprowadzają się do ${ }^{*} g r u s ̌ a /{ }^{*} k r u s ̌ a$, natomiast pozostałe

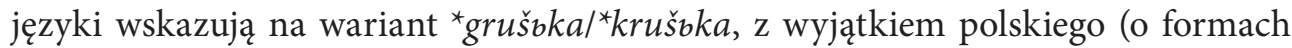
łużyckich i czakawskich zob. niżej), gdzie poświadczone są obie formy (OLA-ls 4: 42-43). Dystrybucja nazwy gruszki (owocu) wygląda bardzo podobnie; zasadnicza różnica polega na większym obszarze występowania form ${ }^{\star} g r u s ̌ s k a /{ }^{*} k r u s ̌ b k a, k t o ́-$ 
re sięgają do dialektów zachodniej Ukrainy (okazjonalnie pojawiają się w gwarach

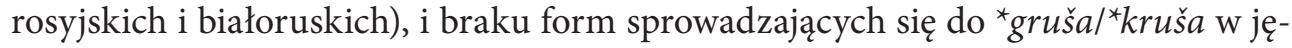
zyku polskim (ibid.: 40-41). Pol. grusza w źródłach pojawia się dopiero w XVIII w., co sugeruje, że jest postacią młodszą od gruszki znanej już z przekazów z XIV w. Istnieją pewne przesłanki pozwalające przypuszczać, że na tych obszarach znany był wariant wyrazu odmieniający się według tematów na ${ }^{*}$-jū , który zachował się na peryferiach i w toponimii, por. głuż. krušej, D. lp. krušwje, płb. grausai (< ${ }^{*}$ gruši $)$, ch. czak. kruši, hrušva, pol. n.m. Kruszwica. Objaśnienie postaci ${ }^{\star} k r u s ̌ z k a$ jako pochodzącej od *kruši (SEBań I: 488-489) wydaje się hipotezą lepiej odpowiadającą materiałowi. Zasięg formy ${ }^{*} k r u s ̌ a l^{*}$ gruša pierwotnie ograniczony był zapewne do areału wschodniosłowiańskiego i grupy bułgarsko-macedońskiej (zob. OLA-ls 4: 40-43), polskie grusza najpewniej jest derywatem wstecznym od gruszka, być może powstałym pod wpływem wschodniosłowiańskim (SEBań I: 488)².

1.2. Zastanawiające jest również stpol. kotka 'samiec i samica kota' (SStp; SPXVI), które formalnie może być derywatem od kot, jednak zmiana rodzaju sugerowałaby dotworzenie nazwy samicy od hipotetycznej nazwy gatunkowej 'kot', co w tym wypadku jest scenariuszem mało prawdopodobnym, ponieważ staropolskie znaczenie realne nie różnicuje kota pod względem płci. Femininum †kota (jako podstawa $\left.{ }^{\star} k o t z k a\right)$ nie da się zrekonstruować w oparciu o słowiański materiał porównawczy, chociaż warto zaznaczyć, że większość słowiańskich nazw gatunkowych tego zwierzęcia stanowią feminina, jednak oparte na różnych rdzeniach, por. cz. kočka, głuż. kóčka, dłuż. kocka; ros., błr. kóška, ukr. kiška, bg. kótka, sła. mačka, ch./serb. mačka, mac. mačka, słe. mâčka i mâček ${ }^{3}$. Języki, z którymi Słowianie sąsiadują od dawna, również pokazują tutaj femininum, por. stwysniem. kazza 'kot', lit. katẽ $\tilde{e}^{4}$, stpr. catto ${ }^{5}$. Słowiańskie ${ }^{\star} k o t z$ najczęściej odnosi się do określenia kocura, z wyjątkiem polskiego i kilku wschodniosłowiańskich gwar (głównie ukraińskich i białoruskich), gdzie oznacza zarówno kotkę, jak i kocura. Na stpol. kotka w znaczeniu gatunkowym wskazuje w szczególności przymiotnik kotczy (SEBań I: 803-804), który w XV-XVI w. ma dużo wyższą frekwencję niż koci lub kotowy i pojawia się głównie w nazwach botanicznych, np. kotcza mądka (SStp IV: 173), kotcza miętka (ibid.: 250), kotczy mrug (ibid.: 360), kotczy ogon (SStp V: 536), kotcze ziele (SPXVI), ale szesnastowieczne przekazy dowodzą również znaczenia 'należący, podobny do kota’ (ibid.). Szerszy zasięg psł. ${ }^{\star} k o t z k a ~ j a k o$ nazwy ogólnej potwierdza strus. kotzka

2 Jeden z recenzentów artykułu zwrócił moją uwagę na możliwość wtórnego zróżnicowania wyrazów grusza (drzewo) : gruszka (owoc) na wzór śliwa (drzewo) : śliwka (owoc), za co, jak i inne cenne spostrzeżenia, w tym miejscu dziękuję.

3 Maskulinum uważa się za wtórne (Snoj 2016: 396). Odnośnie do zasięgu poszczególnych form zob. OLA-ls 2: 72-73.

4 Lit. gw. kãtas uważa się za derywat wsteczny od katẽ (Smoczyński 2018: 505).

5 Znane tylko ze złożenia Paustocatto 'Wilde katze' (Toporov 1980: 269). 
w Latopisie ławrentiewskim (SDJ IV: 277), co jest pierwszym poświadczeniem nazwy tego zwierzęcia na gruncie wschodniosłowiańskim.

W kontekście rekonstrukcji ${ }^{\star} k o t ø k a$ jako nazwy gatunkowej punktem wyjścia mogłaby być forma ${ }^{\star} k o t y,{ }^{\star} k o t z v e e^{6}$ poświadczona licznie w zabytkach połabskich (M. lp. tötåa, M. lm. tötvåi < < koty, $\left.{ }^{\star} k o t z v y^{7}\right)$, chociaż wyprowadzana przez badaczy od m. ${ }^{\star}$ kotz (por. SEJDP: 890-891) niepoświadczonego w połabskim ${ }^{8}$. Derywacja femininum na ${ }^{*}-\bar{u}$ od maskulinum na ${ }^{*}-o$ jest zjawiskiem słabo zbadanym i nie najlepiej udokumentowanym w słowiańskim; najczęściej do tej grupy włącza się ${ }^{\star} k u r y$, ${ }^{\star} k u r \varpi v e$ 'nierządnica, prostytutka' $\leftarrow{ }^{\star} k u r z$ oraz ${ }^{\star} k r o k y, k r o k z v e$ 'krokiew' $\leftarrow{ }^{\star} k r o k z$ '. Głównym kontrargumentem przeciwko traktowaniu pierwszego z wyrazów jako zapożyczenia ze stwysniem. huora jest nagłosowe ${ }^{\star} k$ - w słowiańskim; trudno jednak, żeby był to argument ostateczny, zwłaszcza że da się wskazać przypadki wzmocnienia $x$ w sąsiedztwie $r$, por. stcz. korúhev, ukr. korohva, korohóv (Hrin II 286) : pol. choragiew, psł. ${ }^{*}$ morky: ${ }^{*}$ mzrxy. Godne uwagi są starsze przekazy czeskie <hurwa> (1511 r.), <hurwy> (XVI w.), pokazujące, że w XVI w. związek z psł. ${ }^{\star} k u r z$ nie istniał; $<h>$ w zapisach mogło zostać restytuowane pod późniejszym wpływem niemieckim.

1.3. Stpol. miętka 'Mentha $L$.' jest interesująca nie tylko ze względu na potencjalny związek z tematami na ${ }^{*}-\bar{u}$, lecz także jako podstawowa w tekstach staro- i średniopolskich nazwa omawianej rośliny. Formy, które bezpośrednio odzwierciedlają psł. *męta, są bardzo nielicznie reprezentowane w źródłach (7 razy w SStp, raz w SPXVI) w przeciwieństwie do miętki, która pojawia się w tekstach pół wieku wcześniej (1419 r.) i jest zdecydowanie liczniej poświadczona w zabytkach XV-XVII w. (zob. SStp, SPXVI, KartXVII-XVIII). Na przekształcenie na gruncie polskim psł. *męty, D. lp. ${ }^{*}$ mętrve (por. głuż. mjatej, D. lp. mjatwje, słe. mętva, ch./serb. mëtva, strus. mjatva) wskazuje wariant miętkiew (1437 r.), który najprościej objaśnić kontaminacją miętka i miętew, przy czym to ostatnie reliktowo zachowało się w gwarach (Tomaszewski 1930: 154).

W literaturze można odnaleźć jeszcze kilka przykładów podobnej substytucji; por. kasz. matka 'kawałek kory zdjętej wraz z pączkiem z drzewa o owocach szlachetnych, wszczepiony w nacięcie zrobione w dziczce, zraz' : matev 'ts.', kasz. mótka 'tymotka' : mòtev 'ts.'; bg. želka 'żółw' : želva 'ts.' (SEK III: 226- 227; SEK IV: 355).

6 Warto zwrócić uwagę, że substytucję sufiksu *-øva przez * ${ }^{\star}$ øka obserwujemy w wyrazach o identycznej strukturze segmentalnej: stpol. kotew : kotka 'kotwica'. Związek kotwicy z kotem wydaje się jednak dyskusyjny (zob. Vlajić-Popović 2009).

7 Końcówka M. lm. jest połabską innowacją.

8 Na nazwanie samca ustaliła się pożyczka dolnoniemiecka koter/töter.

9 Szerzej to zagadnienie oraz przypadki typu stpol. wnukiew omawiam w dalszej części artykułu. 


\section{Problem identyfikacji tematów na *-̄̄}

Dotychczas nie wskazano wyraźnych kryteriów pozwalających jednoznacznie stwierdzić, czy ${ }^{*}-v$ - w temacie danego rzeczownika jest rzeczywistym reliktem tematu na ${ }^{*}-\bar{u}$, sufiksem słowotwórczym niemającym bezpośredniego związku z tematami na ${ }^{*}-\bar{u}$ czy wreszcie elementem labialnym niedeterminowanym fleksyjnie lub słowotwórczo. Powszechnym zjawiskiem w językach słowiańskich jest eliminacja formacji atematycznych poprzez przeniesienie ich do klasy tematycznej. Pierwotne tematy na ${ }^{*}-\bar{u}$ najczęściej są włączane do tematów na ${ }^{*}$ a, por. śrpol. łagwa: łagiew, krokwa : krokiew; stcz. mrkva : mrkev, ukr. cérkva : ros. cérkovb, udokumentowane są jednak zjawiska odwrotne, gdzie wyraz należący pierwotnie do tematów na ${ }^{*}$ - $a$ w epoce historycznej został włączony do klasy kontynuującej tematy na ${ }^{*}-\bar{u}$ (zazwyczaj już przekształconej pod wpływem tematów na *-i), por. słe. brîtev, klętev, molitev < ${ }^{\star}$ britva, ${ }^{\star} k l e ̨ t v a,{ }^{*}$ modlitva, pol. dial. brzytew. Poniżej spróbuję wskazać kilka przykładów z materiału słowiańskiego, które mogą sugerować, że poświadczenie rzeczownika kontynuującego typ fleksyjny na ${ }^{*} \bar{u}$ w epoce historycznej niekoniecznie musi dowodzić jego pierwotnej przynależności do danej klasy.

\subsection{Segment *-v- a jakość spółgłoski kończącej rdzeń}

Nieostrożnie byłoby założyć, że wszystkie wyrazy, których temat kończy się na ${ }^{*}-v$-, są przekształceniem dawnych tematów na ${ }^{*}-\bar{u}$. Franciszek Sławski w swoim słowniku (SESł III: 141) rekonstruował konkurencyjne formy typu ${ }^{\star}$ korsta : ${ }^{\star} k o r s t v a$ lub ${ }^{\star} v$ brsta : : vorstva bez łączenia ich $\mathrm{z}$ tematami na ${ }^{*}-\bar{u}$. Formy te można uznać za paralelnie utworzone wyrazy z sufiksami ${ }^{*}-t a{ }^{*}{ }^{*}-t v a$, jednak materiał słowiański pokazuje co najmniej dwa zakończenia tematu, które często rozszerzane są niemotywowanym $v$. Pierwszym są sekwencje typu *-st-, pozostałe zakończone są spółgłoską welarną, por.: stcz. drasta/drásta: drastva 'drzazga, odłamek'; stcz. plásta (również plást m.) : : plástva 'plaster miodu'; stcz. pomsta : pomstva 'pomsta'; cz. hlísta (również hlíst), pol. glista : kasz. glistva, dłuż. glistwa, głuż. hlistwa; pol. podusta, sła. dial. podusta (ros. podúst m.) : stpol. podustwa, cz. podustva, podustev 'świnka pospolita'; pol. pacha, ukr. dial. pácha (również ros. pach m. 'pachwina') : ukr. páchva 'pachwina'; pol. dial. warzecha, warzęcha : warzachew; cz. luska, pol. łuska, głuż. łuska : pol. dial. łuskiew; scs. kønigy, stpol. księgi : dłuż. arch. knigwy 'książka' ${ }^{10}$.

10 Por. też osobliwe przykłady litewskie: brastà : brastvà 'bród'; ląstà : ląstvà 'ptasia klatka'; laktà : : laktvà 'drążek w klatce dla ptaków'; garšvà 'podagrycznik' : łot. gars, psł. ‘gorxz; širta : širtvà 'łoże niedźwiedzia' (Smoczyński 2018: 142, 317, 663, 670, 1386-1387). 
W literaturze najczęściej można się spotkać z poglądem, że produktywność tematów na ${ }^{*}-\bar{u}$ znacząco wzrosła u kresu epoki prasłowiańskiej ${ }^{11}$. Pogląd ten oparty jest na podciąganiu pod ten model deklinacyjny zapożyczeń głównie germańskich i romańskich, trudno jednak nie odnotować, że temat większości tych wyrazów zakończony jest spółgłoską tylnojęzykową (Pronk-Tiethoff 2013: 245), np. *bersky,

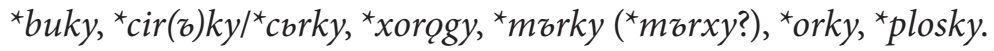

Wśród wyżej wymienionych zakończeń rdzenia znamienny jest brak substytucji sufiksu ${ }^{*}-\approx v-$ przez $^{*}$ - $\_k a$, co może sugerować, że produktywność tematów na ${ }^{*}-\bar{u}$ wcale nie wzrosła w późnym prasłowiańskim, a przeciwnie - rozpoczął się proces eliminacji klasy atematycznej poprzez substytucję sufiksu, który nie objął wyrazów o morfemie rdzennym zakończonym spółgłoską welarną i - przypuszczalnie (zob. niżej) - sekwencją *-st-, co tłumaczyłoby zauważalną produktywność fleksji na *-(j)ū zarówno wśród zapożyczeń, jak i wyrazów rodzimych. Pary typu ${ }^{\star} b r c ̌ i:{ }^{\star} b z c ̌ b k a$, ${ }^{\star} k o t y:{ }^{\star} k o t z k a$ byłyby wówczas reliktem procesu przedhistorycznego, jednak dokładne ustalenie skali zjawiska nie jest możliwe, ponieważ wszelkie ustalenia pozytywne wymagałyby przynajmniej śladowego zachowania sufiksu ${ }^{\star}$ - $\boldsymbol{b} v$-.

Nie ma jasnego kryterium, które pozwoliłoby stwierdzić, czy spółgłoska labialna $\mathrm{w}$ formach typu cz. podustva, podustev jest pozostałością po temacie na ${ }^{\star}-\bar{u}$, nieumotywowanym elementem o funkcji strukturalnej, oddzielnym sufiksem ${ }^{\star}$-tva czy też wtórnie syngularyzowanym sufiksem collectiwów ${ }^{\star}$-va rekonstruowanym na podstawie np. pol. dziatwa, ros. detvá 'larwy pszczół, młode pszczoły; dzieci' (dokładniej o tym zob. 2.4).

\subsection{Feminina na *-ū dotworzone do maskulinów na *-o}

Najbardziej wyrazistym przykładem na parę femininum na ${ }^{\star}-\bar{u}$ i masculinum na ${ }^{*}$-o jest ${ }^{*}$ svekry : ${ }^{\star}$ svekrø, przy czym jest to jedyny pewny przypadek, gdzie femininum na ${ }^{*}-\bar{u}$ ma nawiązania pozasłowiańskie, por. wed. śvaśrū- f., łac. socrus $\mathrm{f}$., stwysniem. swigar f. 'świekra' (Derksen 2008: 475). Pewna produktywność femininów na ${ }^{\star}-\bar{u}$ w nazwach słowiańskich stopni pokrewieństwa została już dostrzeżona (Bernstein 1985: 267); do tej kategorii zostało przyłączone psł. ${ }^{\star} j e ̨ t r y$, które pierwotnie było tematem na ${ }^{\star}$-er- (por. lit. jéntè, gen. sg. jénters; wed. jātar-) i ${ }^{\star} z$ zbly, gdzie formy przypadków zależnych o temacie ${ }^{*}-\approx v$ - być może zastąpiły pierwotny temat na ${ }^{*}-s-$ w oparciu o formę nom. sg. ${ }^{*} z \sigma l y<{ }^{*} g l h_{2} \bar{o} s, \mathrm{z}$ rozwojem wygłosowego ${ }^{*}-\bar{o} s>$ $>$ psł. ${ }^{\star}-y$, który ma paralelę w zaimkach osobowych ${ }^{\star} v y<u ̄ o ̄ s,{ }^{\star} m y<n o ̄ s$ (Witczak 1998: 134-135). Co prawda, ani ${ }^{\star} j e ̨ t r y$, ani ${ }^{\star} z$ zbly nie posiadają swoich odpowiedników rodzaju męskiego, jednak istnieje szereg femininów mocyjnych sugerujących związek z tematami na ${ }^{\star}-\bar{u}$. Z jednej strony mamy serb.-cs. pastorøky 'pasierbica', stpol.

11 Zob. np. Bernstein 1985: 169-170. 
wnukiew, które obok wyjątkowych form na ${ }^{*}-\bar{u}$ funkcjonowały raczej jako feminina na ${ }^{*}-a$ (serb.-cs. pastorøka, słe. pastorka; stpol. wnuka, stcz. vnuka, strus. vønuka), $z$ drugiej - typ odmiany na ${ }^{*}-\bar{u}$ pojawia się wśród femininów derywowanych od maskulinów z sufiksem *-(j)akz: strus. mužakov<b> 'istota dwupłciowa', cs. šestakvica 'sześciolatka', strus. tretijaky, D. lp. tretbjakzve 'trzylatka', serb.-cs. sbrqždakva 'rodzicielka', cs. junakvica 'dziewczynka' (Miklosich 1865; Arumaa 1985: 64-65), który wariantu femininum o temacie na ${ }^{*}-a$ nie posiada ${ }^{12}$.

Przypadki typu stpol. wnuk: wnuka: wnukiew raczej nie powielają wprost stosunku ${ }^{\star}$ svekry : ${ }^{*}$ svekrø, a pokazują ogólną tendencję do wprowadzania femininów na ${ }^{*}-\bar{u} \mathrm{w}$ obrębie terminów pokrewieństwa w oparciu o istniejące już ${ }^{\star}$ svekry, ${ }^{*}$ jętry, ${ }^{*} z \check{b} l y$, chociaż nie bez znaczenia wydaje się tu kończąca temat spółgłoska tylnojęzykowa. Trudno przyjąć, że ten stosunek mógłby być nagle odzwierciedlony w nazwach samic, dlatego też etymologia ${ }^{\star} k u r y$ od ${ }^{\star} k u r ø$ jest pozbawiona wiarygodnej paraleli (i sama jej stanowić nie powinna).

Przywołane tu wyrazy mają w większości charakter efemeryczny, niewielki zasięg i występują przede wszystkim po spółgłosce tylnojęzykowej kończącej temat. $\mathrm{O}$ ile tematy na ${ }^{*}-\bar{u}$ mogły być usuwane $\mathrm{z}$ systemu po spółgłoskach innych niż welarna, o tyle wydaje się, że po welarnych utrzymała się ich pewna produktywność, która częściowo tłumaczyłaby w poszczególnych językach słowiańskich wtórne przyporządkowywanie niektórych wyrazów do tematów na ${ }^{*}-\bar{u}$.

\subsection{Tematy na *-ū powstałe $z$ sekwencji ${ }^{*}-n(\zeta) v$-jako adaptacja stwysniem. geminaty -nn-}

Na uwagę zasługuje kilka zapożyczeń ze staro- i średnio-wysoko-niemieckiego z geminatą -nn-, które w słowiańskim zostały włączone do tematów na ${ }^{*}-\bar{u}$, por. psł. ${ }^{*} k o n y$ $\leftarrow$ stwysniem. kanna, psł. ${ }^{\star}$ pany $\leftarrow$ stwysniem. pfanna, stcz. nunvicě $\leftarrow$ stwysniem. nunna/nonna, stpol. łanwa 'łągiew' $<$ śrwysniem. lanne oraz - już późniejsze - pol. dial. rynwa $<$ rynna $\leftarrow$ śrwysniem. rinne ${ }^{13}$. Taka geminata $\mathrm{w}$ słowiańskim musiała zostać usunięta - na przypadek ${ }^{\star} k o n y$ zwrócono uwagę w ESSJ (X: 196), gdzie

12 Nie można wykluczyć, że powyższe przykłady świadczą o istnieniu sufiksu *-(j)aky.

13 Na związek między tematem na ${ }^{*}-\bar{u}$ w słowiańskim a geminatą w języku, z którego wyraz przejęto, zwrócił uwagę Aleksandar Loma (1994: 18-19), jednak dokumentował on zjawisko dowolną geminatą: ${ }^{\star} b ъ c ̌ i<$ łac. wulg. buttša < łac. buttia; ${ }^{*}$ smoky 'figa' $<$ goc. smakka; serb./ch. letva/latva 'łata dachowa' $\leftarrow{ }^{\star}$ laty $\leftarrow$ stwysniem. latta; głuż., dłuż. nunwa 'wieprz' $\leftarrow$ niem. Nonne; ratwa 'szczur' $\leftarrow$ $\leftarrow$ niem. Ratte. Zdaniem badacza drugi element geminaty w słowiańskim był percepowany jako labializowany, z pauzą między spółgłoskami, która została później zidentyfikowana $\mathrm{z}{ }^{\star}$ b. Przyswojone wyrazy, których temat zakończony był sekwencją ${ }^{*}-C \varpi v V$-, włączono do tematów na ${ }^{*}-\bar{u}$ ze względu na podobieństwo osnowy. Powyższe przykłady są kontrowersyjne, a sama hipoteza trudna do udowodnienia, ponieważ obecność geminaty (lub jej brak) nie determinuje przyporządkowania zapożyczenia do tematów na ${ }^{*} \bar{u}$. 
zasugerowano, że doszło do dysymilacji ${ }^{*}-n n->^{*}-n v->^{*}-n z v-\left(\right.$ pierwotnie $\left.{ }^{*} k o n z v a\right)$ i wyraz ten - jak i resztę przypadków - wtórnie przyporządkowano do fleksji na ${ }^{*}-\bar{u}$.

Inne geminaty nie pokazują już tak wyraźnego związku z tematami na ${ }^{*}-\bar{u}$. Wśród resonantów do powyższego modelu może nawiązywać ${ }^{\star} k u r z v a$ jako adaptacja stwysniem. huorra < ${ }^{\star}$ hōrjōn-, która była wariantem stwysniem. huora < ${ }^{\star}$ hōrōn(Kroonen 2013: 240). O paralelę trudno, ponieważ zachodniogermańskie ${ }^{*} r$ zazwyczaj geminacji nie podlegało (Braune 2004: 99).

\section{4. *kuropzty 'kuropatwa', * ploty 'płotka', *oty 'kaczka' (?) - tematy na *-ū a nazwy zwierząt}

Wśród wyrazów uważanych za pierwotne tematy na ${ }^{\star}-\bar{u}$ zauważalną grupę stanowią nazwy zwierząt. Końcówki fleksyjne bezpośrednio nawiązujące do tematów na ${ }^{*}-\bar{u} \mathrm{w}$ większości wyrazów z tej grupy są poświadczone w epokach historycznych poszczególnych języków słowiańskich, por. cz. koroptev, strus. utovb. Osobliwość ich wiąże się ze współwystępowaniem śladów po tematach na ${ }^{*}-\bar{u} z$ innymi typami fleksyjnymi oraz poświadczeniem postaci sufigowanych, co wyraźnie odróżnia je

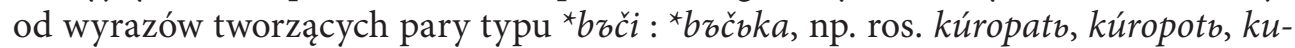
ropátka, pol. dial. kuropatka; ros. dial. plotíca, plotb, pol. płotka, płoć; ros. útka, dłuż. huśica, błr. ucb. Pomimo wczesnego przekazu strus. utovo (XIII w.) większość wyrazów nie pokazuje wyraźnego związku z tematami na ${ }^{*}-\bar{u}$. Na niekorzyść rekonstrukcji *kuropøty świadczą przede wszystkim dane staroczeskie; najstarsze zapisy $<k u$ roptwa> (od 1376 r., por. Gebauer II) sugerują rekonstrukcję *kuropztva. Gdyby stcz. kuroptva była przekształceniem tematu na ${ }^{*}-\bar{u}$, wówczas postacią oczekiwaną byłaby $\dagger k u r o p e t v a<\dagger k u r o p z t z v a^{14}$, tymczasem nie dysponujemy żadnym zapisem staroczeskim z -e-. W materiale łużyckim również nie ma śladu po jerze, por. głuż. kurotwa, kurotej (gen. sg. kurotwje); dłuż. kurwota, kurota (Schuster-Šewc 1982: 736-737). Wtórne -a- $\mathrm{w}$ pol. kuropatwa, ros. dial. kuropatva prawdopodobnie rozbija grupę spółgłoskową powstałą po zaniku jeru ${ }^{15}$. Jeżeli zaginiona n.m. Kuropatniki jest derywowana wprost od ${ }^{*} k u r o p z t v a$, to najstarsze zapisy odzwierciedlają rozwój regularny: <de Kuropetnyky> 1363 r., <de Kuropethniky> 1377 r. < ${ }^{*}$ kuropotvonik-, ${ }^{16}$ chociaż derywacja od wariantu niesufigowanego nie może zostać z góry wykluczona.

Gdyby założyć, że omawiana grupa wyrazów wywodzi się odpowiednio $\mathrm{z}{ }^{\star} k u r o p r t v a,{ }^{*}$ plotva, ${ }^{*}$ Qtva , to możliwe by było wskazanie w nich sufiksu tworzącego collectiva ${ }^{\star}-v a$, jak w ${ }^{\star}$ dětva (SPsł III: 171$)^{17}$. We wschodniosłowiańskim, gdzie

14 Taka praforma znajduje odbicie w wyjątkowym stpol. < curopethfi $>$ (połowa XV w.).

15 Tak też postaci z - $a$ - objaśnia Franciszek Sławski, chociaż zanik jeru tłumaczy wyrównaniem do formacji na ${ }^{*}$-tva (SESł III: 408).

16 Przekazy późniejsze pokazują już nawiązanie do apelatywu kuropatwa: <de Curopadnicz>1393 r., $<$ de Curopatwice $>1404$ r., <Curopatwniki> 1407 r. (NMPol V: 490).

$17 \mathrm{Nb}$. zarówno ${ }^{\star}$ dětva, jak i ${ }^{\star} k u r o p z t v a,{ }^{\star}$ plotva, ${ }^{*}$ ttva mają poświadczony temat na ${ }^{*}-{ }^{\star}:{ }^{\star}$ dětb, ${ }^{*}$ kuropztb, ${ }^{*}$ plotb, ${ }^{*}$ ots. 
produktywność sufiksu *-va została utrzymana, wszystkie wyrazy funkcjonują jeszcze jako collectiva: błr. kuropátva 'stado kuropatw' (Nosovič 1870: 261), ros. plotvá, błr. dial. vútva (ESBM II: 236), ros. dial. utvá. Znaczenia i formy syngulatywne typu pol. kuropatwa, ch. ütva, słe. Q̂tva, mogły powstać wtórnie - w zachodnio- i południowosłowiańskim proces został spowodowany prawdopodobnie utratą produktywności sufiksu ${ }^{*}$-va i dotworzeniem form M. $\mathrm{lm}$. według modelu tematów na ${ }^{*}$ - $a$; strus. singulativum utovb ze względu na chwiejność paradygmatów wyrazów kończących się na ${ }_{-}-(\tilde{b}) v a$ nie jest jeszcze argumentem przesądzającym o pierwotności tematu na ${ }^{\star}-\bar{u}$.

Tworzenie nazw kolektywnych tych gatunków nie powinno dziwić - płotki pływają gromadnie, kaczki są ptakami stadnymi, kuropatwy przez całą jesień i zimę żyją w stadach od kilku do kilkudziesięciu sztuk. Trudno jednoznacznie stwierdzić, czy nie należałoby do tej grupy zaliczyć również przypadków typu pol. pluskwa, kasz. glistva ${ }^{18}$, stpol. podustwa.

Połączenie nazw zwierząt $\mathrm{z}$ collectiwami na ${ }^{*}$-va i wtórnym włączaniem ich do typu deklinacyjnego kontynuującego tematy na ${ }^{*}-\bar{u}$ w poszczególnych językach wydaje się rozwiązaniem prostszym niż objaśnienie produktywności sufiksu -va we wschodniosłowiańskim.

\subsection{Tematy na ${ }^{-j}$ jü}

Tematy na ${ }^{*}$-jū nie mają materiału porównawczego w innych językach indoeuropejskich, co sugeruje, że muszą być słowiańską innowacją. Osobliwe w tej kategorii jest to, że w jej skład wchodzą głównie zapożyczenia lub wyrazy, których rodzimość

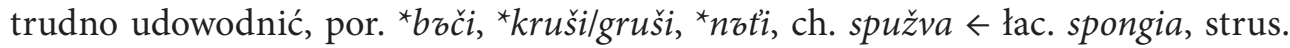
okøševb 'siekiera; oksza' zapożyczone ze źródła germańskiego, por. pgerm. ${ }^{\star} a k w e s i ̄-f$.

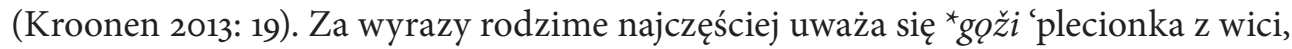
gałązek, najczęściej w formie pierścienia, ${ }^{*} d e ̌ z ̌ i ~ ' d z i e z ̇ a ', ~ * l y z ̌ i ~ ' n a r t a, ~ ł y z ̇ w a '{ }^{19}$. Chociaż

18 Autorzy Słownika prasłowiańskiego (SPsł VII: 111) opowiadają się za oddzieleniem ${ }^{\star}$ glisty od ros. glistvá f. coll. 'robaki do łowienia ryb'.

19 Tematy na *jū mają również poświadczenia w polskiej hydronimii, np. Huczwa, Giełczew. Związek pierwszej z nich z pol. huczeć został przekonująco zakwestionowany (Babik 2001: 131-133), związek drugiej z nich z psł. `gzlkz 'hałas, wrzask, huk, łoskot' (Mól 1990: 14) jest mało prawdopodobny; sam rdzeń nie funkcjonuje również jako podstawa do tworzenia nazw wodnych. Przypisywanie nazwom wodnym na ${ }^{*}$ jū rodzimej proweniencji (tak np. Rieger 1989/1990) obarczone jest dużym ryzykiem; wydaje się, że najpierw trzeba dowieść, że typ ten był produktywny w derywacji w oparciu o leksykę apelatywną. Dopóki ostatni warunek nie zostanie spełniony, trudno nazwy wodne na ${ }^{*}$-jū uznać za rodzime. Ostatnio podjęto próbę rekonstrukcji psł. * malji, *maljbve w oparciu o ros. dial. malbvá 'narybek' i pol. nazwę wodną Malwina (Babik 2017: 53-54). Przekazy rosyjskie nie są jednoznaczne; poza malbvá poświadczone są również postaci malogá i malıgvá, niewykluczone więc, że malıvá pochodzi z uproszczenia grupy spółgłoskowej. Formy 
semantyka ${ }^{\star} g q z ̌ i$ wyraźnie nawiązuje do rodziny * vęzati i przykłady na protetyczne ${ }^{*} g$ - zamiast ${ }^{*} v$ - znane są ze słowiańskiego (zob. SPsł VIII: $176-177$ ), to nie jest to zmiana regularna, więc trudno oprzeć na tym przypadku zagadnienie derywacji tematów na ${ }^{*}$ jū od podstaw rodzimych. Pozostałe dwa przykłady mają ograniczone zasięgi i sprowadzają się już do etymologii pierwiastkowych (zob. SPsł III: 198-199, SEBor: 308), trudno przewidzieć, czy nie są wariantami wtórnymi i stosunkowo nowymi. Wyrazy te nie stanowią najpewniejszych przykładów do studiów nad historycznym słowotwórstwem.

\section{Skróty}

arch. - archaiczny; bg. - bułgarski; błr. - białoruski; ch. - chorwacki; coll. - collectivum; cs. - cerkiewnosłowiański; cz. - czeski; czak. - czakawski; dial. - dialektalny; dłuż. - dolnołużycki; f. - femininum; głuż - górnołużycki; goc. - gocki; gw. - gwarowy; kasz. - kaszubski; lit. - litewski; łac. - łaciński; łac. wulg. - łacina wulgarna; łot. - łotewski; m. - masculinum; mac. - macedoński; n.m. - nazwa miejscowa; niem. - niemiecki; pgerm. - pragermański; płb. - połabski; pol. - polski; psł. - prasłowiański; ros. - rosyjski; scs. - staro-cerkiewno-słowiański; serb. - serbski; sła. - słowacki; słe. - słoweński; stcz. - staroczeski; stpol. - staropolski; stpr. - staropruski; strus. - staroruski; stwysniem. - staro-wysoko-niemiecki; śrpol. średniopolski; śrwysniem. - średnio-wysoko-niemiecki; ukr. - ukraiński; wed. - wedyjski

\section{Literatura}

ArumaA P., 1985, Urslavische Grammatik, t. 3: Formenlehre, Heidelberg.

BАВIK Z., 2001, Najstarsza warstwa nazewnicza na ziemiach polskich (w granicach wczesnośredniowiecznej Słowiańszczyzny), Kraków.

BАвІк Z., 2017, Glosa czy nazwa terenowa? O dwóch dyskusyjnych miejscach XV-wiecznych ksiąg ziemskich, „Język Polski” XCVII, s. 49-58.

BERNSTEIN S., 1985, Zarys gramatyki porównawczej języków słowiańskich. Alternacje, tematy imienne, tłum. J. Wawrzyńczyk, Warszawa.

Boryś W., 1974, Deminutywa typu „,brzemiączko”, „ramiączko”, „Język Polski” LIV, s. 119-124. Braune W., 2004, Althochdeutsche Grammatik I. Laut- und Formenlehre, Tübingen.

DERKSEN R., 2008, Etymological Dictionary of the Slavic Inherited Lexicon, Leiden - Boston. ESBM: V.U. Martynaŭ (red.), Ėtymalagičny sloŭnik belaruskaj movy, t. 1-, Minsk 1978-.

z wokalizmem rdzennym - $a$ - pochodzą z gwar akających, ale w formach, gdzie akcent spoczywa na rdzeniu, i w gwarach północnorosyjskich mamy -o-, por. mols 'drobne ryby', móloga 'strzelba potokowa', mólska 'narybek', molvkí 'drobna suszona ryba', molvë 'narybek; drobna suszona ryba; okonie, płotki, szczupaki’ (SRNG XVII: 342-343, SRNG XVIII: 250, Vasmer II: 648-649), zatem związek z przymiotnikiem * malo jest dyskusyjny. W kontekst ros. dial. malıvá potencjalnie uwikłana jest również produktywność sufiksu -va (zob. 2.4). 
ESSJ: O.N. Trubačev (red.), Ėtimologičeskij slovar' slavânskih âzykov. Praslavânskij leksičeskij fond, t. 1-, Moskva 1974-.

Gebauer J., Slovník staročeský, t. II: [K-N], wyd. 2, Praha 1970.

Hrin: B. Hrinčenko, Slovar' ukraïns'koï movy, t. I-IV, Kï̈v 1907-1908.

KartXVII-XVIII: Kartoteka Słownika języka polskiego XVII i 1. połowy XVIII w., w Zakładzie Językoznawstwa PAN w Warszawie, [on-line:] https://www.rcin.org.pl/dlibra/ publication/20029.

KroOnen G., 2013, Etymological Dictionary of Proto-Germanic, Leiden - Boston.

Loma A., 1994, Osamnaest vekova u tri slova: toponim „Niš” kao živi spomenik prošlosti, [w:] N. Bogdanović (red.), U svetlu carskih gradova, Niš, s. 7-26.

Miklosich F., 1865, Lexicon Palaeoslovenico-Graeco-Latinum, Vindobona.

MóL H., 1990, Gewässernamen im Flußgebiet des Wieprz, Stuttgart.

NMPol: K. Rymut (red.), Nazwy miejscowe Polski. Historia, pochodzenie, zmiany, t. I-, Kraków 1996-.

Nosovič I.I., 1870, Slovar' belarusskogo narečiâ, Sanktpeterburg.

OLA-ls 2: J. Basara (red.), Obščeslavânskij lingvističeskij atlas. Seriâ leksiko-slovoobrazovatel'naja, t. 2: Životnovodstvo, Warszawa 2000.

OLA-ls 4: A. Ferenčiková (red.), Obščeslavânskij lingvističeskij atlas. Seriâ leksiko-slovoobrazovatel'naja, t. 4: Sel'skoe hozâjstvo, Bratislava 2012.

Pronk-Tiethoff S., 2013, The Germanic Loanwords in Proto-Slavic, Amsterdam - New York.

RIEger J., 1989/1990, Polska nazwa wodna „Giełczew” i jej południowosłowiańskie odpowiedniki, „Makedonski jazik” XL/XLI, s. 483-485.

SCHUSTER-ŠEWC H., 1978-1989, Historisch-etymologisches Wörterbuch der ober- und niedersorbischen Sprache, Bautzen.

SDJ: P.I. Avanesov (red.), Slovar' drevnerusskogo âzyka (XI-XIV vv.), t. I-, Moskva 1988-.

SEBAń: A. Bańkowski, Etymologiczny słownik języka polskiego, t. 1-2, Warszawa 2000.

SEBor: W. Boryś, Słownik etymologiczny języka polskiego, Kraków 2005.

SEJDP: K. Polański, Słownik etymologiczny języka Drzewian połabskich, z. 1-6, Wrocław Warszawa - Kraków 1962-1994 [z. 1 wspólnie z T. Lehrem-Spławińskim].

SEK: W. Boryś, H. Popowska-Taborska, Słownik etymologiczny kaszubszczyzny, t. I-VI, Warszawa 1994-2010.

SESŁ: F. Sławski, Słownik etymologiczny języka polskiego, t. I-V, Kraków 1952-1982.

Smoczyński W., 2018, Lithuanian Etymological Dictionary, Berlin.

SNOJ M., 2016, Slovenski etimološki slovar, Ljubljana.

SPsı: F. Sławski (red.), Słownik prasłowiański, t. I-VIII, Wrocław - Warszawa - Kraków - Gdańsk 1974-2001.

SPXVI: Słownik polszczyzny XVI wieku, t. I-IV, red. komitet redakcyjny, t. V-XVII, red. M.R. Mayenowa, t. XVIII-XXXIV, red. F. Pepłowski, t. XXXV-XXXVI, red. K. Mrowcewicz, P. Potoniec, Wrocław - Warszawa - Kraków 1966-2012.

SRNG: F.P. Filin (red.), Slovar' russkih narodnyh govorov, t. I-, Moskva 1965-.

SSTP: S. Urbańczyk (red.), Słownik staropolski, t. I-XI, Warszawa 1953-2002.

Tomaszewski A., 1930, Gwara Łopienna i okolicy w północnej Wielkopolsce, Kraków.

Toporov V.N., 1980, Prusskij âzyk. Slovar' I-K, Moskva.

Vaillant A., 1958, Grammaire comparée des langues slaves, t. 2: Morphologie, Lyon - Paris.

VASMER: M. Fasmer, Ėtimologičeskij slovar' russkogo âzyka, t. I-IV, Moskva 1986-1987. 
Vlajić-Popović J., 2009, Proto-Slavic *koty, -ъve 'Anchor', 'Cat' or Something Else?, [w:] I. Janyšková, H. Karlíková (red.), Studia etymologica Brunensia, t. 6, Praha, s. 377-388. WitczaK K.T., 1998, Dwa terminy prasłowiańskie w ujęciu diachronicznym (1. ${ }^{*}$ zъly > $>^{*}$ zblъva 'szwagierka, siostra męża', 2. * plo 'otwarta przestrzeń wodna), „Slavia Occidentalis" 55, s. 133-138.

\section{Identification of *-(j)ü-stems in Polish and Slavic Material Summary}

The paper discusses the question of the substitution of the stem suffix ${ }^{*}-\imath v$ - for the suffix ${ }^{\star}-\imath k a$, which converts words from the ${ }^{*}-(j) \bar{u}$ - to the ${ }^{\star}$ - $a$-declension, as well as the problem of identification of original ${ }^{*}-(j) \bar{u}$-stems. An analysis of Polish and Slavic material leads to the conclusion that a part of nouns that are commonly regarded as ${ }^{*}-(j) \bar{u}$-stems have in fact a different origin: some can be derived from collective nouns in ${ }^{*}-v a$ (still productive in East Slavic), e.g. ${ }^{*} k u r o p r t v a,{ }^{*}$ plotva, ${ }^{*}$ tva , and a part have probably been extended with an unmotivated labial element $-v$ - which has the appearance of a relic of a ${ }^{*}-\bar{u}$-stem, but appears most commonly after roots that end in a velar consonant or a spirant-stop sequence. The paper argues against the hypothesis about late (Proto-)Slavic activization of ${ }^{*}-\bar{u}$-stems and proposes instead that a part of this class had been eliminated at a prehistoric stage, depending on the quality of the stem consonant. 